\title{
Sustainable development through the prism of ethno-tourism - example of Montenegro
}

\author{
Boban Melović ${ }^{1, *}$, and Dragana Ćirović $^{1}$ \\ ${ }^{1}$ Faculty of Economics, University of Montenegro, 81000 Podgorica, Montenegro
}

\begin{abstract}
This article is exploring the possibilities for sustainable development trough the instignation and improvement of ethnotourism in Montenegro. This article identifies the current level of development of ethnotourism, the forms in which it is being expressed, and gives the recommendations for its improvement. The results show that, despite the significant tourism potential that Montenegro has, this type of tourism is still in its initial phase of development and it takes place within the ethno-villages bussines in the northern region of the country. The tourism offer isn't diversified enough. It is based on natural resources and traditional cuisine, but it doensn't contain the elements specific for this type of tourism, wich would convey the spirit of montenegrin culture and tradition to the tourists in a better way. Therefore it is necessary to make additonal efforts in the forthcoming period, in order to develop it. This goal can be achieved trough better cooperation of decision-makers on state and local level, and trough the empowerment of the offerers to take over the initiative in order to enrich their tourism offer with elements from Montenegrin traditon.
\end{abstract}

\section{Introduction}

The concept of sustainable development represents the specific philosophy and strategy of social development, which appeared as a result of concern about environmental pollution and irrational use of non-renewable natural resources. Until today, the importance of this concept was growing in parallel with the development of awareness that economic growth by itself isn't enoguh to ensure long-term existence and welfare, unless it is accompanied by an improvement of overall qualty of life of all participants. The term 'sustainable development' first appeared in 1987. with the publication of the Brundtland report (report of the World Commisson on Environment and Development) as a warning to negative environmental impacts that previous economic growth and globalistation had, in order to find possible solutions for the problems caused by exaggerated industrialisation and overpopulation [1-13]. There is no unique definiton of sustainable development. The most widely adopted is the one given by Brundtland Commision and it says that: 'sustainable development is the development that meets the needs of the present without compromising the ability of future generations to meet their own needs' [14]. This indicates that the mentioned concept implies finding alternative directions of economic development and

*Corresponding author: bobanm@ac.me 
social prosperity, which will provide rational use of resources and which will be in line with principles of environmental protection. However, the focus of sustainable development is much wider than environmental protection and the main goal of application of this concept is to create strong, healthy and equitable society. It implies meeting different needs of present and future generations trough promoting personal welfare, social cohesion and inclusion and trough creating equal possibilities for all members of society [14]. The accomplishment of that goal is possible only through the implementation of main principles of sustainable development (the principle of holistic approach, the principle of social justice, the principle of sustainable resource management, the principle of integration, the principle of local resources usage, the principle of social responsibility, the principle of internalising of external effects...) in all economic activities of society $[7,10]$.

The acquirement of long-term economic stability with the preserved environment is the main goal of implementation of the stated principles of sustainable development. In order to make it possible, decision makers should create specific development strategies which are integrating three core elements of sustainability: economic growth, social inclusion and environmental protection [15]. Economic sustainability, as one of three main dimensions of sustainable development, implies balanced economic development and equal distribution of economic resources. Social cohesion and inclusion implies improvement of the quality of peoples' lives trough human rights protection, creating better access to education and health care, and trough creating equal opportunities for everyone. Ecological sustainability implies rational use of resources, investment in renewable energy sources, implementation of innovations and application of ecological strandards in all areas of ecnonomic activity [13].

Taking into account the importance of implementation of sustainable development for developing countries, such as Montenegro, it is necessary for each country to formulate its own sustainable development strategy, which will be based on resources that the county has and on defined priority directions of socio-economic development. Montenegro is one of the countries who integrated the requirements of United Nations' Agenda for Sustainable Development 2030 into its national system and also defined a strategy of sustainable development and management of its human, social, natural and economic resources based on those requirements. At the same time it defined main objectives of sustainable development: eradication of poverty trough providing easier access to the necessary services and resources; balanced, fair and long-term sustainable economic development; rational and sustainable use of energy and natural resources; streghtening and proteciton of cultural identity; encouraging cooperation between different social agents in order to create peaceful and sustainable environment $[6,13]$. The mentioned strategy also defines the main directions of activities for decision makers, but special attention is paid on development of defined priority areas: tourism, energetics, industry and agriculture. The economic structure that has been built in the past period isn't adapted to the sustainable development requirements and is mostly based on polluting industries and unsustainable exploitation of natural resources. Besides of that, the current trends in the development of tourism in the coastal area have led to the accelerated urbanization, conversion of agricultural land into constructional land and caused the northern region to lagg behind in terms of socio-economic development (which represents one of the main economic problems) [6]. Therefore, the key challenges of the country's future development include the implementation and acceleration of economic reforms, provision of balanced economic development and the associated challenges of improvement of living strandard and reduction of poverty. Montenegro is an ecological country which possesses preserved natural resources and great potentials for tourism development in all aress and, therefore, making efforts in the sustainable tourism development in the northern region is a good strategy that can provide economic prosperity of rural areas of the country.

\section{Ethno-tourism as a type of sustainable development}


In recent years tourism has became one of the fastest growing economic branches in the world and today (along with related industries such as catering) adds up to $10 \%$ to the world GDP $[8,12]$. However, inadequate tourism management causes numerous negative impacts on the environment, economy, culture and a whole society. This problem is particularly conspicuous in the less developed countires, where previous tourism development was accompanied by high rates of foreign ownership (which causes loss of the control over local resources), insufficient interconnection with other economic branches, the growth of socio-economic inequality, strong fluctuation of revenues due to the seasonal character of tourism acitvities, destruction of environment and irreversible loss of nonrenewable resources [4, 8]. Therefore, it is necessary to integrate the principles of sustainability into tourism development strategy, i.e., to develop so-called sustainable tourism. Sustainable tourism can be defined as development of tourism acitivities and meeting the needs of tourists along with achievement of economic, social and aesthetic benefits, but in a way that the cultural integrity, main ecological processes, biodiversity and principles that create well-being of all memebers of society are respected [4, 8].

The development of sustainable tourism concept has led to the growing popularity of different types of tourism, which are based on natural potentials of destination and which contribute to the preservation of its natural resources and cultural heritage. One of those types of tourism is ethno-tourism. It is defined as a specific type of tourism aimed at familiarizing tourists with the culture, architecture, tradition and lifestyle of people who live (or have lived) in a particular tourist destination [2,9]. It is based on the desire of tourists to explore the specific cultural heritage, language and customs of certain ethinc communities. Thus, it contributes to the preservation of the cultural identity of local communities and maximizes their economic and social benefits without negative impacts on the environment. The ethnotourism development contributes to the growth of employment and economic recovery of rural areas, it encourages the development of micro, small and medium enterprises and the development of related economic acitivities (agriculture, catering...), it promotes the traditional artistic events and contributes to the preservation of local craft skills $[3,11]$. Because of the direct contact between tourists and local population, the ethno-tourism development contributes to better understanding and strengthening of the connections between representatives of different cultures. Therefore, the development of this type of tourism allows to the local communities to generate significant income, which is usually used for future improvement of quality of local peoples' lives (trough development of education, health services, etc.) $[12,13,14]$. The main agents of the ethno-tourism development are local communities. Therefore, they must acquire the ability to offer specific experience to the tourists and also to monitor and evaluate the impact of tourism on culture and natural environment. In order to make this goal achievable it is necessary that the governmental structures provide adequate support to the local communities in terms of planning, capacity building and providing information, but also it is necessary that the government makes an additional efforts in order to train local communities for indipendent decision making in the field of planning, organizing and delivering the tourism offer [5].

\section{Ethno-tourism in Montenegro}

Tourism is one of the main pillars of the montenegrin economy. In 2016. the share of new added value of this sector in the total GDP of the country was $22.1 \%$ (including direct and indirect contributions). Direct contribution of this sector to the total labour employment was $6.5 \%$, while its indirect contribution was $14.6 \%$ [16]. Due to its importance for generating employment, increasement of the living standard of the population and balanced regional development, tourism has been recognized as one of the priority economic sectors in the country. Decision that tourism should be the driving force of the economy and the new 
development cycle is based on the fact that this sector generates the development of other complementary activities, such as transport, trade, banking, agriculture, etc. That creates a number of positive effects, such as reduction of unemployment, growth of a living standard of the population and balanced development of rural areas (it makes people to stay in the countryside and reduces the problem of aging of the villages, trough development of agriculture and tourism types which are strongly connected with countryside and agriculture). However, the curent tourism development is mainly attached to the coastal area of the country, it has obvious seasonal character and is based on exploitation of natural resources (space. water, fuel, electricity and food) which causes significat amounts of waste and pollution $[6,7]$. This led to increased pressure on the environment of the southern region and unbalanced regional development. Therefore, the development focus in the forthoming period should be placed on sustainable forms of tourism, such as ethno-tourism.

Ethno-tourism in Montenegro is based on activities of so-called 'ethno-villages'. However, the establisment of these villages is related to initiatives of individuals and they are organised as private entrepreneurial enterprises. Some of the most famous ethno-villages are: Montenegro, Jatak, Nevidio, Milogora i Izlazak.

Ethno-village Montenegro is the first village of this type in our country. It is established in 2006. and it is located near Plužine. The tourist season in this ethno-village lasts from spring to autumn (approximately 5 months). Beside of traditional dishes from Montenegrin cuisine, it offers various types of activities to the tourists: river rafting, the jeep safari over Durmitor ring, Piva lake cruising and many other hiking tours. It owns 28 huts designed at recognizable style of Montenegrin architecture. Therefore, tourists can choose the type of accommodation they want: stone huts, chalets or a luxury apartment [17]. It seeks to position itself as an ethno-village that transmits the original spirit of Montenegrin culture and the traditional lifestyle of the Montenegrin population. For this purpose it publishes several books and brochures based on preservation of Montenegrin culture and tradition (A guide to healing planst in Piva, Montenegrin cookbook, Beauty and antiquities of Montenegro, etc.) and also is one of the initiators of organic production program. During the season this ethnovillage is visited by more than 250000 tourists, mostly foreigners. Its marketing promotion is based on publicity (trough posting an articles in newspapers and hosting their representatives in various television shows), website with convinient user interface and 'word-of-mouth' marketing.

Ethno-village Jatak is plased in Petnjica and its offer is based on the natural beauties of its location (it is located near lake Prošćenje and the canyon Nevidio - one of the most beautiful canyons in Balkan. This village offers accomodation in double-bed or family huts designed in a mountain construction style (made of wood and stone) and a restaurant with traditional Montenegrin cuisine. It seeks to complete its tourism offer trough adding numerous activities, such as hiking, canyoning, biking and fishing. Tourists here can also find a souvenir shop with products inherent to the Montenegrin culture [18].

Ethno-village Nevidio is located in the mountain Durmitor. The offer of this village indludes possibility for tourists to pass trough the Nevido canyon, several bike trails designed for mounatain cycling lovers and seven hiking trails. It is also an excellent choice for all alpisnism lovers due to steep terrain of this destination. Tourists are accommodated in one of nine bungalows made of wood and stone [19].

Ethno-village Milogora, located in the mountain Tara, is designed in an ambient style and consists of six bungalows. It offers numerous activities to the tourists, such as sightseeing of cultural and historical monuments, rafting, cycling, boat riding, hiking, riding horses and ponies, etc [20].

Ethno-village Izlazak is located in near the Piva canyon, in the place called Rudinice. The tourist offer of this village is also based on the natural beauties of its location. It is made of bungalows and huts (traditionaly and modern furnished) and a restaurant 'Koliba Izlazak' 
which offers traditional Montenegrin dishes. Besides of comfortable accommodation, playground for the youngest visitors and terrains for small football and volleyball, tourists here can enjoy in cycling, rafting, doing the jeep photo safaries, lake cruising and so on [21].

The analysis of the avaliable ethno-tourism offer in Montenegro showed that this type of tourism is still in its initial stage of development. The offer is mostly based on traditional Montenegrin cuisine and on beauty and deversity of natural resources, but there are no many opportunities for tourists to truly meet the traditional lifestyle of people here (which is one of the main goals of ethno-tourists). The tourism offer of existing ethno-villages consists of activities such as cycling, hiking and rafting, but much more emphasis should be placed on specific activities which are inherent to the ethno-tourism. The tourism offer isn't diversified enough and it obviously has a seasonal character. There is a lack of clear diversification of the regions in terms of precise definition and recognizability of their tourism offer and their offer isn't complemented by characteristics of regional art, culture and tradition. Their natural, climatic, cultural and historical specificities aren't clearly visible. There is no enough attention paid to the traditional styles of construction and its incorporation into natural environment $[1,7]$.

Therefore, a lot of effort should be made in order to enrich the tourism offer, so that the significant potential for development of ethno-tourism, that Montenegro has, can be used. The offerers can stimulate the interaction of tourists with local population living near etnovillages. They can aslo organise thematic literary evenings, folklore evenings, original music events, or workshops on traditional Montenegrin crafts and involve the tourists in the process of preparing traditional dishes. A lot of things still should be done in order to improve the existing offer and provide a higher level of tourists' satisfaction. These are only few recommendations which can be implemented in a relatively short period of time and with modest financial resources, but whose implementation would strongly affect the recognition of ethno-tourism offer in Montenegro in a positive way. The Agenda of tourism reforms in Montenegro [1] recommends realization of certain activities in order to enrich the ethnovillages offer. One of them relates to investment into development of old crafts in certain parts of the country. Presentation of crafts with the possibility for tourists to participate in some parts of the production process would become an interesting segment of certain destinations' offer, such as production of gusle or dvojenice (traditional musical instruments) or wooden dishes in the northern part of the country. It is also recommended to bind cultural heritage complexes (e.g. old mills, medieval fortresses, prehistoric habitats inside the caves...) and form a tours.

In the forthcoming period it is necessary to pay more attention to the promotion too. The promotion of existing ethno-villages is mostly based on their websites and cooperation with travel agencies, and relies on promotional activities of the National Toursim Organisation of Montenegro to a large extent. Within the framework of the previous activities of this organisation various types of promotion have been realized, such as fair events on important emitting markets, promotional campaigns in the neighboring countries' markets, study tours for important media, promotional campaigns on CNN and BBC television networks and so on [1]. However, these promotional ativities are mainly aimed at promoting Montenegro as a toursim destination, without emphasizing the specific tourism offerings of certain destinations. Therefore, it is necessary that the offerers in this branch of tourism take over the initiative, in order to better promote and attract new tourists.

\section{Conclusion}

Acceleration of economic reforms, improvement of living standard and reduction of poverty are some of the key challenges of Montenegro's sustainable development. Solving these challenges implies the necessity of making additional efforts, in oreder to esnure balanced 
economic development in sustainable way. Montenegro is characterized by significant differences in the level of development, which is manifested trough underdeveloped northern region and developed central and souther regions. However, the nothern region includes more than half of the territory of the country and it has significant natural resources suitable for the development of various types of tourism. [6,7] Since tourism is recognized as one of the priority branches of future development, its improvement in the northern region is imposed as a proper strategy, with the aim of future economic prosperity of this part of Montenegro. This region is especially suitable for the development of ethno-tourism, thanks to its natural resources. However, ethno-tourism is still in the initial stage of development. The ethnotourism offer isn't diversified, it is based on natural beauties of destination and is characterized by the lack of important specific elements which would properly reflect the spirit of the cultrure and tradition in Montenegro. Therefore, attention must be paid to the improvement of the offer of ethno-villages and to their promotion in the forthcoming period. It is also necessary to establish better cooperation between decision-makers at the state and local level. Additional effort must be made in order to train the ethno-tourism offerers to take over the initiative, so that the full potential for development of this type of tourism in Montenegro can be used.

\section{References}

1. Acton plan for preparation of tourist season - agenda of reforms in the field of tourism. Podgorica: Ministry of Sustainable Development and Tourism of Montenegro (2013).

2. A. Aleksandrova, E. Aigina, SHS Web of Conferences 12, 01036 (2014)

3. S. Bolnick, Promoting the culture sector through job creation and small enterprise development in SADC countries: the ethno-tourism industry. ILO (2003)

4. J. Brohman, Annals of tourism research, 23(1), 48-70 (1996)

5. T. H. Lee, Tourism management, 34, 37-46 (2013)

6. National strategy for sustainable development by 2030. Podgorica: Ministy of Sustainable Development and Tourism of Montenegro (2016)

7. National strategy for sustainable development 2007 - 2012. Podgorica: Government of the Republic of Montenegro, Ministry of Tourism and Environmental Protection (2007)

8. S. Y. Pan, M. Gao, H. Kim, Science of the Total Environment, 635, 452-469 (2018).

9. A. Polukhina, Worldwide Hospitality and Tourism Themes, 8(3), 359-372 (2016)

10. Transforming our world: the 2030 Agenda for Sustainable Development, United Nations. A/res/70/1 (2015)

11. Travel and Tourisim Economic Impact 2017 - Montenegro. World Travel \& Tourist Council (2017)

12. Tourism Highligths. World Tourism Organisation (2017)

13. https://www.acciona.com/sustainable-development/\# - official website of a company ACCIONA

14. http://www.sd-commission.org.uk/pages/what-is-sustainable-development.html official website of Sustainable Development Commission

15. https://www.enb.gov.hk/en/susdev/sd/index.htm - official website of Environement Bureau in Hong Kong

16. https://bestwritingservice.com/essays/Description/Ethno-Tourism.html - official website of a company Best Writing Service

17. http://etnoselo.me/ - official website of ethno-village Montenegro 
18. http://www.jatak.me/index.html - official website of ethno-village Jatak

19. http://www.etnoselonevidio.com/index.php - official website of ethno-village Nevidio

20. http://milogora.me/ - official website of ethno-village Milogora

21. http://www.etno-selo-izlazak.me/ - official website of ethno-village Izlazak 